\title{
Çingenelerde Yoksulluk ve Sosyal Dışlanma: Malatya Örneği*
}

\section{Poverty and Social Exclusion in Gypsies: The Case of Malatya}

\author{
Muhammet Frrat, ${ }^{\mathrm{a}, * *}$ Süleyman İlhan, ${ }^{\mathrm{b}}$ \\ ${ }^{a}$ Dr. Öğr. Üyesi, Fırat Üniversitesi İnsani ve Sosyal Bilimler Fakültesi Sosyoloji Bölümü, 23270, Elazı̆̆/Türkiye. \\ ORCID: 0000-0002-2447-1427
}

${ }^{\text {b }}$ Doç. Dr., Fırat Üniversitesi İnsani ve Sosyal Bilimler Fakültesi Sosyoloji Bölümü, 23270, Elazığ/Türkiye. ORCID: 0000-0002-6549-3462

\section{MAKALE BILGGISI}

Makale Geçmişi:

Başvuru tarihi: 01 Ağustos 2018

Düzeltme tarihi: 26 Ekim 2018

Kabul tarihi: 03 Ocak 2019

\section{Anahtar Kelimeler:}

Çingene/Dom

Yoksulluk

Sosyal Dişlanma

Dezavantajlılık

\section{ARTICLE INFO}

\section{Article history:}

Received 01 August 2018

Received in revised form 26 October 2018

Accepted 03 January 2019

\section{Keywords:}

Gypsy/Dom

Poverty

Social Exclusion

Disadvantageousness

\section{ÖZ}

Çingeneler günümüzde, yoksulluk ve sosyal dışlanmayı çok dramatik biçimde deneyimleyen dezavantajlı gruplardan biridir. Giderek yerleşik hayata geçmelerine rağmen, yoksulluk ve dışlanmanın nesnesi olmaya devam etmektedirler. Bu çalışmada, Malatya'da yaşayan Çingenelere yoksulluk ve sosyal dışlanma bağlamında yaklaşılmaktadır. Bu kapsamda, Çingenelerdeki yoksulluk ve sosyal dışlanma; etnisite, yoksulluk nedenleri, göç ve göçe bağlı sorunlar, eğitim hizmetlerinden yeterince yararlanamama, istihdam olanaklarına yeterince ulaşamama ya da güvencesiz çalışma, sosyal güvenlik ağlarından yoksun olma, sosyal yardımlardan faydalan(ama)ma, sağlıksız konutlarda yaşama, ayrımcılık vb. dezavantajları içermektedir. Araştırmada, Çingenelerin hem kültürel hem de sosyo-ekonomik açıdan "dezavantajlı bir grup" olduğu, yoksulluk ve sosyal dışlanmayı şiddetli bir şekilde deneyimlemelerinde kendi paylarının da bulunduğuna inandıkları saptanmıştır.

\section{A B S T R A C T}

Gypsies is one of the disadvantaged groups that experience poverty and social exclusion dramatically. Despite the fact that they settle in time, they have been the subject of exclusion. In this study, poverty and social exclusion that Gypsies that live in Malatya experience is examined within the context of poverty and social exclusion. In this scope, the study includes disadvantages as poverty and social exclusion in Gypsies, ethnicity, the reasons of poverty, migration and migration-related problems, low-access to education and employment services and opportunities or precarious work, being deprived of social security networks, not being able to benefit from social aid, accommodating in unhealthy housings, decimation etc. In the study, it was determined that Gypsies is a "disadvantaged" group from both cultural and socio-economic aspects, and Gypsies believe that they also play a role in terms of experiencing severe poverty and social exclusion.

\section{Giriş}

İçinde yaşadıkları toplum tarafından genelde tehlikeli, ahlaksız, hırsız, dilenci, cahil vb. sifatlarla damgalanan Çingeneler, sosyal, kültürel ve ekonomik açıdan topluma yeterince katılamamış, yoksulluk ve sosyal dışlanmanın en dramatik hallerine maruz kalmış dezavantajlı bir gruptur. Ancak dezavantajlılık Çingenelerde, diğer gruplardan farklı biçimlerde deneyimlenmektedir. Marsh (2008: 53)'ın da ifade ettiği gibi, sosyal yoksunlukların sadece Çingene gruplarını etkilemediği gerçeğine rağmen, Çingenelere karşı geliştirilen önyargılar, onların özelde yoksulluk ve sosyal dışlanma gibi problemleri daha şiddetli yaşamalarına sebebiyet vermektedir. Kimlikleri nedeniyle ayrımcılığa uğrayan Çingenelerde, bu durumun diğer yoksul grupların yaşadıklarından daha ciddi boyutta olduğu görülmektedir.

* Bu çalışmada Muhammet Fırat'ın 2016 yılında Fırat Üniversitesi Sosyal Bilimler Enstitüsü’nde tamamladığı "Çingeneliği Anlamanın İmkânı: Çingeneler Üzerine Sosyolojik Bir Araştırma (Malatya Örneği)” başlıklı doktora tezinden kısmen yararlanılmıştır.

** Sorumlu yazar/Corresponding author.

e-posta: muhammetfirat@ firat.edu.tr 
İstihdam, eğitim, barınma, sosyal güvenlik gibi temel haklara yeterince erișemeyen Çingenelerin bu sorunları, geçmişten günümüze süregelmektedir. Öyle ki yoksulluk ve sosyal dışlanma nedeniyle Çingeneler, böylesi temel haklardan bile faydalanamamakta, vasıf gerektirmeyen, geçici, güvencesiz ve düşük ücretli enformel işlerde çalışmakta, eğitim sürecinde sağlıklı yol alamamaktadırlar. Genellikle, bulundukları şehrin kenar mahallerinde yaşayan Çingeneler, kentin sosyal ve kültürel imkânlarından da yeterince yararlanamamaktadırlar.

Türkiye'de yaşayan Çingeneler; Rom, Lom ve Dom olmak üzere üç gruba ayrılmaktadır. Bu gruplar; yaşadıkları coğrafi bölge, dilleri, istihdam kolları ve yaşam tarzları açısından birbirlerinden farklılık göstermektedir (Kolukırık 2008: 149). Bu çalışmada, Malatya'da yaşayan Dom grubu Çingeneler ${ }^{1}$ ele alınmaktadır. Bu Çingeneler, Doğu ve Güneydoğu Anadolu'nun (Elazı̆̆g, Diyarbakır, Mardin, Şanlıurfa, Gaziantep, Hatay, Malatya ve Adıyaman gibi) birçok ilinde yaşayan Çingene topluluklarıdır. Malatya'da yaşayan Çingeneler, diğer Çingene topluluklarına kıyasla haklarında en az bilgiye sahip olunan Çingene gruplarındandır. Bu Çingenelerin çoğu, Marsh (2008: 22)'a göre, Ortadoğu'daki Dom Çingenelerinin bir koludur ve Türkiye'nin doğusu ve güney doğusuna (Diyarbakır, Antakya, Mardin, Malatya, Elazı̆̆, Adıyaman) 11. yüzyılın başlarında gelmişlerdir.

Araştırma alanını oluşturan Malatya'nın Koşu, Yeşilkaynak, Fatih, Hoca Ahmet Yesevi, Seyran, Y1ldıztepe ve Tandoğan mahalleleri, gecekondulaşmanın yoğun olduğu ve derin yoksulluğun yaşandığı, şehrin kıyısında konumlanmışlardır. Malatya'nın yerli halkı bu bölgelerde nadiren ikamet etmektedir. Ancak bazı mahallelerde Çingenelerin yanı sıra Van, Muş, Bingöl ve Bitlis illerinden göçle gelen hanelere de rastlanmaktadir.

Araștırma alanı olarak belirlenen Malatya'nın bu kenar mahallelerinde, Çingeneler (Dom) küçük ve sağlıksız barakalarda ikamet etmekte, adeta getto tarzı bir yaşam sürdürmektedirler. Bu mekânlarda ikamet eden Çingenelerin otantik özelliklerini çok büyük ölçüde korudukları söylenebilir. Böylesi homojen yerleşim mekânlarının yanı sıra, Çingene olmayanlarla (Gaco) aynı mahallelerde ikamet eden Çingeneler de vardır. Buralarda yaşayanlar da özgünlüklerini büyük ölçüde muhafaza etmektedirler.

$\mathrm{Bu}$ çalışmada, genel kabul görmüş bir üst kimlik belirteci olması, gündelik dildeki işlevselliğii, kapsayıcılığı ve Türkçe literatürde Çingene sözcüğünün yaygınlığı ve yerele de vurgu yapması, Çingene adının tercih edilmesinde etkili olmuştur.

Çingeneler üzerine yapılan araştırmalarda, son zamanlarda bir artış eğilimi gözlenmektedir. Ancak Çingenelerin yaşadıkları toplum içerisindeki konumlarını çeşitli değişkenler bağlamında sosyolojik açıdan irdeleyen araştırmalar yeterli düzeyde değildir. Çingeneler gibi dezavantajlı bir gruba sosyolojik perspektiften yoğunlaşan bu çalışmanın, Çingenelerin sorunlarının çözümüne ve literatüre katkı sağlaması umulmaktadır.

\footnotetext{
${ }^{1} \mathrm{Bu}$ çalışmada, genel kabul görmüş bir üst kimlik belirteci olması, gündelik dildeki işlevselliğii, kapsayıcılığı ve Türkçe literatürde
}

$\mathrm{Bu}$ araștırmada Çingenelere yoksulluk ve sosyal dışlanma özelinde yaklaşılmakta, Çingenelerin eğitim, göç, hane durumları, sosyal güvence, iş/uğraş alanları, aylık ortalama gelirleri, yoksulluk nedenleri, sosyal yardımlardan faydalanma durumları, dışlanma alanları ve dışlanmalarında kendilerinin payı gibi yoksulluk ve sosyal dişlanma araştırmalarında önemli sayılabilecek göstergelere yoğunlaşılmaktadır.

Çalışmanın birinci bölümünde araştırmanın yöntemine, ikinci bölümde araştırmanın bulgularının değerlendirilmesine, üçüncü bölümde ise sonuca yer verilmektedir.

\section{Yöntem}

Malatya'da yaşayan Çingenelerde yoksulluk ve sosyal dişlanmaya odaklanan bu çalışma, bir alan araştırmasına dayanmaktadır. Özkan'ın (2010: 29) yaptığı bir araştırmaya göre, Malatya'da 3000 civarında Çingene yaşamaktadır. Araştırmamızın zamansal olarak yerel seçimlerin hemen öncesine rastlaması nedeniyle güncellenmiş seçmen listelerine ulaşma imkânı da söz konusu olmuştur. Muhtarlıklardaki seçmen listelerinden, muhtarlardan ve diğer kaynaklardan elde edilen bilgilere göre, Malatya'da ikamet eden Çingenelerin sayısının 5000 civarında olduğu ve bunların 2500'ünün 18 ve üstü yaşlarda olduğu saptanmıştır. Çingenelerin yoğun olarak ikamet ettikleri 7 mahallede (Yeşilkaynak, Koşu, Fatih, Hoca Ahmet Yesevi, Seyran, Yıldıztepe ve Tandoğan) 249 kişi ile anket uygulaması gerçekleştirilmiştir. Örneklem, \%10'luk oranla araştırma evreni üzerinden basit tesadüfi örnekleme tekniğiyle oluşturulmuştur.

Araştırmada kantitatif yaklaşımın yanı sıra, kalitatif yaklaşıma da başvurulmuştur. Bu kapsamda yüz yüze anket ve mülakat yoluyla veriler toplanmıştır. Alan araştırması bizzat araştırmacı tarafından uygulanmıştır. Alan araştırmasından elde edilen veriler, SPSS 16.0 (Statistical Packages For Social Sciences) programı ile analiz edilmiş ve oluşturulan basit dağılım tabloları yorumlanmıştır.

Malatya ilinin araştırma alanı olarak tercih edilmesinde, özellikle, Malatya'da yaşayan Çingeneler üzerine daha önce herhangi bir araştırmanın yapılmamış olması ve burada Çingeneliğin, otantisitesini büyük ölçüde korumakta olması gibi faktörler etkili olmuştur.

\section{Araştırma Bulguları}

\section{1.Çingenelerin Sosyo-Demografik/Ekonomik Durumlar1}

\subsubsection{Cinsiyet Durumlar1}

Cinsiyet, açıklanmaya çalışılan toplumsal gerçekliği anlama açısından önemli bir değişken olarak kabul edilmektedir. Örneklem grubunun cinsiyete göre dağılımı aşağıdaki tabloda yer almaktadır.

Çingene sözcügünün yaygınlığı ve yerele de vurgu yapması, Çingene adının tercih edilmesinde etkili olmuştur. 
Tablo 1. Cinsiyet Dağılımı

\begin{tabular}{lcc}
\hline Cinsiyet & Sayı & \% \\
\hline Erkek & 168 & $\mathbf{6 7 , 5}$ \\
Kadın & 81 & $\mathbf{3 2 , 5}$ \\
\hline Toplam & $\mathbf{2 4 9}$ & $\mathbf{1 0 0}$ \\
\hline
\end{tabular}

Tablodan anlaşılacağı üzere, görüşülenlerin \%67,5'i erkek, \%32,5'i kadındır. Öğrenim düzeylerinin yetersizliği ve bir kısım erkek katılımcıların, hanedeki kadınların ankete katılmasını "gerek yok", "anlamazlar" gibi gerekçelerle engellemeleri kadınların ankete katılımının erkeklere oranla, düşük seviyede kalmasına yol açmıştır. Bununla birlikte, kadın görüşmecilerin \%32,5'lik bir oranda olmaları, Çingenelerin temsili açısından önemlidir.

\subsubsection{Katılımcıların Eğitim Durumları}

Eğitim, yoksulluk ve sosyal dışlanmayla doğrudan ilişkilidir. Örneklem grubunun öğrenim durumları Tablo 2'de yer almaktadir.

Tablo 2: Öğrenim Durumunun Dağılımı

\begin{tabular}{lcc}
\hline Öğrenim Durumu & Sayı & $\mathbf{\%}$ \\
\hline Okur-yazar değil & 43 & $\mathbf{1 7 , 3}$ \\
Okur-yazar & 59 & $\mathbf{2 3 , 7}$ \\
İkokul mezunu & 103 & $\mathbf{4 1 , 4}$ \\
Ortaokul mezunu & 37 & $\mathbf{1 4 , 9}$ \\
Lise ve dengi okul mezunu & 6 & $\mathbf{2 , 4}$ \\
Üniversite & 1 & $\mathbf{0 , 4}$ \\
\hline Toplam & $\mathbf{2 4 9}$ & $\mathbf{1 0 0}$ \\
\hline
\end{tabular}

Tabloda görüldüğü üzere, katılımcıların çoğu $(\% 41,4)$ ilkokul mezunu; \%23,7'si okur-yazar; \%17,3'ü okur-yazar değil; \%14,9'u ilköğretim (ortaokul) mezunu; \%2,4'ü lise dengi okullar mezunu ve \%0,4'ü üniversite mezunudur.

$\mathrm{Bu}$ dağılım, Çingenelerin öğrenim düzeylerinin oldukça düşük olduğunu göstermektedir. Yapılan enformel görüşmelerde, Çingene çocukların, okulda başarılı olamamalarının çeşitli nedenlerinin olduğu saptanmıştır. 48 yaşındaki bir kadın görüşmecinin, "Biz çocuklarımızı mahalle okullarına gönderiyoruz. Mahallede bizim göçer olduğumuzu biliyorlar. Çocuklar bir hafta falan isteyerek okula gidiyor, daha sonra gitmek istemiyor. Çocuklara Çingene falan diyorlarmış. Allah var ögretmenleri çok iyi ama arkadaşlarl dalga geçiyor, Çingene falan diye..." ifadeleri, dişlanma nedeniyle çocukların okuldan uzaklaştıklarını ve bu durumun okulu terk etme ile sonuçlandığını göstermektedir

Dolayısıyla, önyargı, kalıpyargı, dışlama, damgalama gibi sorunlar, Çingenelerin okula hiç gitmemelerine ya da okulu yarıda bırakmalarına neden olmaktadır. $\mathrm{Bu}$ bağlamda, Y1lgür'ün (2012: 139) de belirttiği gibi, marjinal yoksulluk bölgelerinde yaşayanlara, kolay kolay değişemeyecek bir etiket gibi yapıştırılan grup temelli algılar; eğitim olanaklarını olumsuz bir şekilde etkilemektedir. Etnik aidiyetleri ortaya çıktığında, bulundukları alanda önyargılar tarafından kısıtlanmaya başlarlar. 11 yaşındaki bir çocuğa neden okula gitmediği sorulduğunda, dile getirdiği "Beni sevmiyor arkadaşlar, Çingen diyorlar, benle oyun oynamıyorlar, dalga geçiyorlar, ben de daha gitmedim, gitmem de..." ifadeler, birçok dişlanma kombinasyonunu barındırmaktadır. Alandaki başka çocuklar da benzer gerekçeler göstermişlerdir. Çingene damgası ve yoksulluğun acı dünyasını hisseden çocuğun bu ifadeleri, düşük öğrenim düzeylerini açıklar niteliktedir.

Çingenelerde gözlenen eğitim sorununa yönelik, 54 yaşındaki bir görüşmecinin dile getirdiği, "Çocuklarımız anaokullarına ve kreşlere gidemiyor, okul öncesi eğitim alamiyor, maddi durumumuz yok, yeterince ĕgitilemiyor, geriden geliyor. Son zamanlarda içimizde okuyup da memur, ögretmen, doktor, olanlar var ama bunlar da çok az, kaldı ki onlar da çocuklarl okusun diye bizim toplumumuzdan ayr duruyorlar ve bu yüzden bizim çocuklarımı onları kendilerine örnek alamıyor." ifadeleri, Çingenelerin sosyoekonomik ve kültürel imkânlar açısından yetersiz olduklarını, bu nedenle eğitim sürecinde sağlıklı yol alamadıklarını ortaya koymaktadır.

Giddens'ın da belirttiği gibi; klasik sosyolojide, eğitim imkânları sayesinde yoksul çocukların da toplumsal piramidin üst basamaklarına çıkacak yeteneklerle donanabileceklerini, bunun ise, bütün çocukların eğitim olanaklarına eşit koşullarda ulaşmasıyla geçerli olabileceğini belirtmektedir. Ancak son zamanlarda eğitim sosyolojisi alanında yapılan çalışmalarda, eğitim sürecinin sınıfsal veya etnik farklılıkları yeniden üretecek şekilde katmanlaştığına vurguda bulunmaktadır (Giddens, 2008: 432-433). Hem sınıfsal açıdan toplumun alt katmanlarında yer alan hem de çok boyutlu dişlama pratiklerine maruz kalan Çingenelerde, eğitimin katmanlaşma sürecinde olumsuz etkilenmektedirler. Çingeneler örneğinde eğitim, toplumdaki sınıfsal farklılıkları yumuşatacak bir eşitlenme alanı olmaktan çok, onları yeniden üreten bir katmanlaşma alanı olarak belirmektedir (Akkan vd. 2011: 62).

Elde edilen bulgular, Çingeneler üzerine farklı yer ve zamanlarda yapılmış çalışmalarla da örtüşmektedir. Örneğin, Türkiye'de yapılan bir araştırmada, Çingenelerde okur-yazar olmayanların oranı yaklaşık \% 75'tir (FSG, 2010: 12). Alp ve Taştan'ın yaptığı araştırma sonuçlarına göre ise, Çingeneler arasında; okur-yazarlık \%30-40 gibi bir oranla genel olarak Türkiye ortalamasının çok altındadır (2011: 3233). Ayrıca Kolukırık(2006, 9)'ın 2006 yılında Tarlabaşı Çingeneleriyle yaptığı çalışmanın bulgularına göre, okuryazar olmayanların oranı \%25,6, ilkokul eğitimini yarıda bırakanların oranı $\% 17,8$, ilkokul mezunu olanların oranı $\% 37,8$ ve ilkokul sonrası okuma oranı \%12,2'dir.

Öte yandan toplumsal konumun tayininde etkili olan öğrenim durumu, eğitimsiz yoksullar için genelde toplumsalın aşağı katmanlarına işaret etmektedir (İlhan, 2013: 178). Zira yoksulluk halinin süreklileştiği bölgelerde, bireylerin eğitime erişimleri söz konusu yoksulluk hali tarafindan kisitlanmaktadır. Dolayısıyla, toplumun sosyo ekonomik ve sosyo kültürel yapısını ileriye taşıyacak olan öğrenim düzeyinin, Çingenelerde düşük olması, mevcut olumsuz konumlarının devamına hizmet etmektedir.

\section{4. Çingenelerde Yoksulluk ve Sosyal Dışlanmaya İlişkin Bazı Sosyo-Ekonomik/ Kültürel Faktörler}

\subsection{Göç Durumu}

Göç olgusu, yoksulluk ve sosyal dişlanmanın özellikle kentsel alanlarda nasıl yaşandığını saptamak açısından işlevseldir. Dolayısıyla, yoksulluk ve dışlanma araştırmalarında göç durumu büyük öneme sahiptir. Çingenelerin göç durumları Tablo 3'da ele alınmaktadır. 
Tablo 3: Malatya'ya Göç Durumu

\begin{tabular}{lcc}
\hline Göçle Gelme & Sayı & \% \\
\hline Evet & 57 & $\mathbf{2 2 , 9}$ \\
Hayır & 192 & $\mathbf{7 7 , 1}$ \\
\hline Toplam & $\mathbf{2 4 9}$ & $\mathbf{1 0 0}$ \\
\hline
\end{tabular}

Tablo 3'ten anlaşılacağı üzere, Malatya'ya göç ile gelenlerin oran1 \%22,9 iken, hiç göç etmediğini belirtenlerin oranı \% 77 , 1 'dir.

Ancak alanda yapılan görüşmelerde, Çingenelik imgesinin temelini, göçebelikle ilişkilendiren çoğu görüşmecinin, "kendi ailelerinin Malatya'nın yerlisi olduğunu, komşularının göç ile geldiği” yönündeki beyanları, göçle gelenlerin oranının daha yüksek olduğunu düşündürmektedir. Malatya'nın yerlisi olduklarını söyleyen görüşmecilerin, aslında göç geçmişlerinin çok eski zamanlara dayandığı, 1935-1970'li yıllarda dedelerinin göç ettiği bilgisine ulaşılmıștır. Mahalleye ilk göç edenlerin en son göç edenleri "onlar göçer, Çingene, biz Malatyalıyız, yerliyiz” gibi ifadelerle küçümsemeleri ve en son gelenlerin ilk gelenlere Çingeneliklerini devretme çabası olarak düşünülebilir.

Malatya'nın çeşitli mahallelerinde gerçekleştirilen bu çalışmada, göç sürecinde öncelik sırasına göre kente tutunma düzeyinin yüksek olduğu, ilk gelen göçmenlerin, görece daha iyi bir geçinme stratejisi ve kentlilik düzeylerinin olduğu, ancak en son gelen göçmenlerin kente tutunma düzeylerinin düşük olduğu söylenebilir (Işık ve Pınarcıoğlu, 2003). Kentsel alanlara yerleşmek amacıyla yapılan göçler sonucu, kente uyum sağlamada Çingene olmayanlara oranla daha zorlu koşullarla karşı karşıya kalan Çingeneler, göç ettikleri bölgelerde sosyo-ekonomik sıkıntıların yanı sıra, kimlikleri nedeniyle de birtakım zorluklara maruz kalmaktadırlar.

Genelde uzun bir süre yerleşik hayat süren Çingenelerin, göçer ve yarı göçer Çingeneleri, basit yaşantılarından dolayı "Çingene" olarak damgalamak suretiyle kendi kimliklerini gizledikleri gözlenmiştir. Bu durum, Malatya'da ikamet eden Çingenelerin, yerli olduklarını beyan ederek, Çingeneliğin içerdiği olumsuz anlam ve imgelerden kurtulmak istediklerini düşündürmektedir. Dolayısıyla, Çingene mahallelerinde "Çingenelik" sonradan gelenlere atılarak, Çingenelikten aklanma, Çingenelikten azade yeni bir kimlik edinme ve bu kimlik üzerinden topluma eklemlenme yönünde bir çabanın bulunduğu söylenebilir.

\subsection{Göçe Bağlı Sorunlar(1) ve Bu Sorunların Devamı}

Büyük umutlarla göç eden Çingenelerin, geldikleri yerlerde umduklarını bulamamaları çeşitli sorunlara yol açmaktadır. Bu kapsamda, Malatya'ya göç eden Çingenelerin göçe bağlı sorunlarının dağılımı aşağıdaki tabloda yer almaktadır.

Tablo 4: Göçe Bağlı Sorunlarının Dağılımı

\begin{tabular}{lccc}
\hline Göçe Bağlı Sorunlar & Sayı & \% & Geçerli\% \\
\hline Ekonomik sıkıntılar & 19 & 7,6 & $\mathbf{3 3 , 3}$ \\
Çevreye uyum problemi vb. & 9 & 3,6 & $\mathbf{1 5 , 8}$ \\
Dışlanma & 12 & 4,8 & $\mathbf{2 1 , 1}$ \\
Hepsi & 17 & 6,8 & $\mathbf{2 9 , 8}$ \\
Genel Toplam & 57 & 22,9 & $\mathbf{1 0 0}$ \\
Göç olmadı & 192 & 77,1 & \\
\hline Toplam & $\mathbf{2 4 9}$ & $\mathbf{1 0 0}$ & \\
\hline
\end{tabular}

Tablo 4'te de görüldüğü üzere, ekonomik sıkıntılar $(\% 33,3)$ Malatya'ya yerleşen Çingenelerin yaşadıkları sorunların başında gelmektedir. Özellikle, Türkiye'nin Doğu ve Güneydoğu bölgelerinde yaşayan Çingenelerin, kırsala özgü geçim imkanlarının azalmasıyla kentlere göç ederek enformel işlere yöneldikleri bilinmektedir. Mesleki formasyon gerektiren işler konusunda gerekli niteliğe sahip olmaları nedeniyle Çingeneler, emek piyasasında marjinal işlere yönelmektedirler. Böylesi işlerden geçimlerini sağlayamamaları onları yoksulluk sarmalına hapsetmektedir. Ekonomik ve sosyal imkânlara ulaşmaları da mümkün olmadığından durumları daha da zorlaşmaktadır.

Tabloya göre, kente göç edenlerin yaşadığı önemli sorunlardan biri de dişlanmadır $(\% 21,1)$. Bu anlamda, Çingenelerin mekânsal olarak damgalanmış bu mahallelerde yaşıyor olmaları, dışlanmalarını kolaylaştırmaktadır. Örneğin, iş ve sosyal yardımlara başvurularında ikamet bilgilerinin istenmesiyle Çingene olduklarının açığa çıkması, dışlanmalarına neden olabilmektedir. Akkan vd.'nin de (2011: 99) belirttiği gibi, toplumun gözünde Çingene algısını tanımlayan Çingene mekânlarının damgalanması, Çingenelerin toplumla bağlarını koparan ve her alanda yaşanan sosyal dışlanma pratiklerini de belirleyen bir çıkmaz olarak kendini göstermektedir.

Kente göç edenlerin yaşadıkları önemli sorunlardan biri de çevreye uyum $(\% 15,8)$ problemleridir. Yerleşik yaşam tarzına yabancı sayılan Çingenelerin, göç ile birlikte uyum sorunlarının ortaya çıkması; istihdam, barınma, sosyal yardımlara ulaşma, dişlanma gibi birçok sorunu da beraberinde getirmektedir.

Görüşülenlerin yaklaşık üçte biri $(\% 29,8)$, belirtilen sorunların hepsi ile karşılaştıklarını belirtmişlerdir. $\mathrm{Bu}$ bağlamda göç sonucu ekonomik sıkıntılar, çevreye uyum problemleri ve sosyal dışlanma gibi sorunların aslında birbiriyle bağlantılı olduğu yadsınmamalıdır.

Genellikle kente göç edenler, belli bir zaman aralığında göç ettikleri yerlere uyum sağlama ve diğer zorluklarla mücadele yeteneklerini geliştirmektedirler. Önceki kuşaklara mensup göçmenlerin, sorunlarını yeni göçmenlere devretmesiyle birlikte avantajlı konuma geçtikleri birçok araştırmada saptanmıştır (Işık ve Pınarlıoğlu, 2003; Erder, 2001). Göç sonrası devam eden sıkıntılarına ilişkin dağılım Tablo 5'te yer almaktadır.

Tablo 5: Göçten Sonra Devam Eden Sıkıntılar

\begin{tabular}{lccc}
\hline Devam eden sıkıntılar & Sayı & \% & Geçerli \% \\
\hline Ekonomik sıkıntılar & 15 & 6 & $\mathbf{2 6 , 3}$ \\
Çevreye uyum zorluğu & 4 & 1,6 & $\mathbf{7}$ \\
Dışlanma & 30 & 12 & $\mathbf{5 2 , 6}$ \\
Hepsi & 8 & 3,2 & $\mathbf{1 4}$ \\
Toplam & 57 & 22,9 & $\mathbf{1 0 0}$ \\
Göç olmadı & 192 & 77,1 & \\
\hline Genel Toplam & $\mathbf{2 4 9}$ & $\mathbf{1 0 0}$ &
\end{tabular}

Tabloda görüldüğü üzere, görüşülenlerin, \%52,6's1 dışlanma, \%26,3'ü ekonomik sıkıntılar, \%7'si çevreye uyum zorluğunun, \%14'ü ise bu sıkıntıların hepsinin devam ettiğini belirtmişlerdir.

Erder'e göre göç sürecinin bazı özellikleri yoksulların kendi içlerinde katmanlaşmalarına yol açmaktadır. Göçmenlerin geldikleri alanlarda sahip oldukları sermaye birikimleri 
(ekonomik-sosyal sermaye), kente tutunma stratejileriyle doğru orantılı bir rol oynamaktadır. Özellikle küçük kentlerden veya ilçelerden göç eden göçmenlerin daha avantajlı bir konuma sahip oldukları, buna karşın, kente hiçbir sermayeye sahip olmadan gelen grupların hem kente entegrasyon süreci hem de iş piyasasına eklemlenme biçimleri, diğerlerinden çok daha karmaşık özellikler göstermektedir (2001: 288-290). İstihdam ve sermaye bakımından marjinallikleriyle bilinen Çingenelerin, Erder'in de belirttiği gibi kente eklemlenme biçimleri, çoğunlukla Çingene olmayan göçmenlere göre daha zorlu bir hal almaktadır.

$\mathrm{Bu}$ kapsamda, bir önceki tablo (Tablo 4) ile karşılaştırıldığında; ekonomik sıkıntıların ve çevreye uyum problemlerinin azaldığı ortaya çıkmıştır. Malatya'da yaşayan Çingenelerin kente uyum süreci ile geçinme stratejilerini geliştirdikleri ve bu sayede bu zorluklarını azalttıkları görülmektedir. Ancak dışlanma algısının artmasında, kente göç edildikten belli bir süre sonra, bu problemin farkına varılmasının yattığı akla gelmektedir. Zira kimliğin deşifre edilmesinde rol oynayan mekânsal özelliklerin, sosyal dışlanma problemlerini ilerleyen süreçlerde arttırması kaçınılmaz hale gelmektedir.

Madanipour (2003), eskiden olduğunun aksine, günümüzde sosyal dışlanmayı, bazı birey ya da grupların etiketlenmesi ve temel sosyal haklardan mahrumiyet ekseninde gelişen bir süreç olarak tanımlamaktadır. $\mathrm{Bu}$ çerçevede, Çingene damgası ya da sosyal dışlanma göçün başlangıcında asgari düzeyde $(\% 21,1)$ hissedilirken, belli bir süre sonra daha s1k hissedilen $(\% 52,6)$ bir süreç olarak deneyimlenmektedir.

\subsection{Hanede Yaşayan Birey Sayısı}

Haneye ilişkin bulgular, sosyo-ekonomik faktörlerin anlaşılmasında önemli bir göstergedir. Örneklem grubunun yaşadığı hanenin nüfus dağılımı aşağıdaki tabloda yer almaktadır.

Tablo 6: Hane Nüfusu Dağılımı

\begin{tabular}{lcc}
\hline Hanede Yaşayan Birey Sayısı & Sayı & $\mathbf{\%}$ \\
\hline İki & 5 & $\mathbf{2}$ \\
Üç & 10 & $\mathbf{4}$ \\
Dört & 29 & $\mathbf{1 1 , 6}$ \\
Beş & 63 & $\mathbf{2 5 , 3}$ \\
Altı & 41 & $\mathbf{1 6 , 5}$ \\
Yedi+ & 101 & $\mathbf{4 0 , 6}$ \\
\hline Toplam & $\mathbf{2 4 9}$ & $\mathbf{1 0 0}$ \\
\hline
\end{tabular}

Tablo 6'dan da anlaşılacağ1 üzere, görüșülenlerin \%40,6's1 yedi ve üzeri kişi, \%16,5'i altı kişi, \%25,3'ü ise beş kişi ile aynı hanede yaşadıklarını beyan etmişlerdir. $\mathrm{Bu}$ veriler, Çingenelerde hane başına düșen kiși sayısı ortalamasının 5,7 olduğunu göstermektedir. 2016 Tuik, Nüfus ve Konut Araştırmaları verilerine göre, Türkiye Hanehalkı büyüklüğü ortalaması 3,5'tir (www.tüik.gov.tr, 2016). Dolayısıyla araştırmaya konu olan Çingenelerde hane başına düşen kişi sayısı, Türkiye ortalamasının üzerindedir. Hanehalkı nüfus sayısının bu denli yüksek olmasında çocuk sayısının fazla olması, yaşlı anne ve babasıyla birlikte yaşayanların olması ve kocaları hapiste olan kadınların çocukları ile baba evinde ikamet etmeleri gibi faktörler de etkili olmuştur.

Türkiye geneline ilişkin bir raporda hanehalkı büyüklüğü arttıkça yoksulluk riskinin de arttığı ileri sürülmektedir. Hanehalkı büyüklüğü 3 veya 4 kişiden oluşan hanelerde bulunan fertlerin yoksulluk oranı \%13,8 iken, 7 ve daha fazla olan hanelerde fertlerin yoksulluk oran1, \%51,9 olarak belirtilmiştir (www.tüik.gov.tr, 2016). Dolayısıyla, Çingenelerde görülen yoksulluğun önemli bir nedeninin kalabalık haneler olduğu söylenebilir.

\section{4. İkamet Ettikleri Konutun Fiziki Durumu}

Fiziksel görünüşleriyle içinde yaşayanlar hakkında fikir verebilmesi, konutu yoksulluk araştırmalarında işlevsel kılmaktadır (İlhan, 2013: 182). Çingenelerin yaşadıkları konutların fiziksel durumu Tablo 7'de yer almaktadır.

Tablo 7: Yaşanılan Konutun Fiziki Durumu

\begin{tabular}{lcc}
\hline Konut Çeşitleri & Sayı & \% \\
\hline Gecekondu & 96 & $\mathbf{3 8 , 6}$ \\
Apartman dairesi & 2 & $\mathbf{0 , 8}$ \\
Müstakil betonarme & 45 & $\mathbf{1 8 , 1}$ \\
Müstakil kerpiç & 66 & $\mathbf{2 6 , 5}$ \\
Müstakil ahşap & 1 & $\mathbf{0 , 4}$ \\
Baraka & 39 & $\mathbf{1 5 , 7}$ \\
\hline Toplam & $\mathbf{2 4 9}$ & $\mathbf{1 0 0}$ \\
\hline
\end{tabular}

Tabloya göre, görüşülenlerin \%38, 6's1 gecekondu, \%26,5'i müstakil kerpiç ev, \%18,1'i müstakil betonarme ev ve $\% 15,7$ 'si baraka tipi evlerde yaşamlarını idame ettirmektedirler.

Gecekonduda yaşayanların oranının yüksek çıkmasının $(\% 38,6)$ temel nedeni, Çingenelerin genellikle gecekondu mahallelerinde yoğunlaşmasıdır. Malatya'nın kenar mahallelerinde bulunan, genellikle bir arsa üzerine özensiz bir şekilde inşa edilmiş, tek katlı ve sağlık koşulları açısından yetersiz konutların yoğunlaştığ 1 bir profile sahip olan araştırma alanı, Malatya'nın diğer mahalleleri ile mukayese edildiğinde, birer çöküntü alanı olarak değerlendirilebilir. Buralarda yer alan çok sayıda gecekondu tipi konut, genellikle kerpiç ve sonradan eklenmiş tuğla odalarla bütünlüğü olmayan, küçük, bağımsız odacıklar şeklinde geniş bir alana yayılmıştır. Evler genellikle 50-60 $\mathrm{m}^{2}$ civarında olup, sağlık koşulları açısından elverişsizdir. Genelde her konut bir avluya yerleşmiş ve her avluda ortalama iki baraka bulunmaktadır. Arsa üzerine inşa edilen ana konut, genellikle aile büyüklerine aittir. Arsanın her köșesine, evlenen çocukları için, ahșap iskeletli, tek odalı, içeriden karton, ve dışarıdan naylon çadır vb. izole edilmiş baraka tipi konutlar bulunmaktadır.

Arsanın ortasında veya ana konutun içerisinde bulunan banyo ve tuvaletler ortak kullanılmaktadır. Malatya kent alanında bulunan konut tipleriyle kıyaslandığında, oldukça elverişsiz özelliklere sahip Çingene konutları, kendilerinin geliştirdikleri ilkel yöntemlerle inşa edilmiştir. Arsa içerisinde bulunan ana evde anne, baba ve çocuklar yaşamaktadır. İlk evlenen erkek çocuk eși ile birlikte ana konuta yerleşmektedir. Çocuklarını erken yaşta evlendiren aileler, ekonomik bağımsızlığı olmayan bu yeni aileyle aynı konutta yaşamak zorunda kalmaktadır. Daha sonraki çocuklar evlendiklerinde, anne babasıyla aynı evde yaşayan büyük çocuk için ya arsanın bir köşesine karton ya da çadırdan baraka tipi ev inşa edilmekte ya da mevcut evin 
yanına odacık(lar) eklenerek bölünmüş ev ${ }^{2}$ tipi konutlar ortaya çıkmaktadır. Tuvaletin ortak kullanıldığı bazı konutlarda, tuvaletin kapısı bir bez parçası ile ya da teneke parçaları ile yapılmıştır.

Müstakil betonarme ve müstakil kerpiç evlerin çoğu, Malatya'da Afet Evleri adıyla bilinen mahallede yaklaşık 40 yıl önce kamu kuruluşları tarafından deprem vb. doğal felaketlerden etkilenenler için inşa edilmiş, ancak günümüzde genellikle Çingene ailelerin yerleştiği konutlardır. $\mathrm{Bu}$ evlerin temel özellikleri bakımından, gecekondulardan farklı oldukları söylenemez. Genellikle kent merkezine uzak bir arsa içerisinde hurda vb. satış malzemelerinin biriktirildiği bu konutlar, yaşam alanı olma özelliğinin yanında iş etkinliklerinin yürütüldüğü bir mekânlar olarak da karşımıza çıkmaktadır. Dolayısıyla konutların fiziki durumu Çingenelerin yoksulluklarını resmetmektedir.

\subsection{Konutun Hukuksal Statüsü}

Birey için konutun niteliği kadar hukuksal statüsü de önemlidir. Zira bir konut sahibi olmak, Çingeneler için ekonomik rahatlama ve yerleşik yaşama (komşuluk, aidiyet vs.) tekabül etmektedir. Çingenelerin yaşadıkları konutların hukuksal statüsü Tablo 8'de yer almaktadır.

Tablo 8: Konutun Hukuksal Statüsü

\begin{tabular}{lcc}
\hline Konutun Hukuksal Statüsü & Sayı & \% \\
\hline Kira & 64 & $\mathbf{2 5 , 7}$ \\
Bana ait & 75 & $\mathbf{3 0 , 1}$ \\
Ücretsiz & 94 & $\mathbf{3 7 , 8}$ \\
Müşterek & 16 & $\mathbf{6 , 4}$ \\
\hline Toplam & $\mathbf{2 4 9}$ & $\mathbf{1 0 0}$ \\
\hline
\end{tabular}

Araştırmada baraka tipi evler konut bazında ele alınmıştır. $\mathrm{Bu}$ nedenle, ücretsiz konutlarda yaşayanların $(\% 37,8)$ oransal bakımdan yüksek çıkması, ailelerine ait gecekondu arsalarına inşa ettikleri baraka tipi konutların sayıca fazla olmasından kaynaklanmaktadır. Yine ücretsiz konutlar içerisinde az da olsa anne-babalarına ve akrabalarına ait konutlarda yaşayanlar da bulunmaktadır.

Kendilerine ait konutlarda yaşayanlar $(\% 30,1)$, bu konutları önceden cüzi fiyatlarla aldıklarını beyan etmişlerdir. Bu konutların çoğu 1940 ve 1950'li yıllarda satın alınmış olup, bu bölgede yeni konut satın alan yok denecek kadar azdır. Nitekim çoğu görüşmeci bu konutların, babadan kalma olduğunu beyan etmişledir. Kendilerine ait bir eve sahip olmak, özellikle de bir gecekonduya sahip olmak, her yoksul konutta olduğu gibi Çingeneler için de barınma işlevinin yanında geçinme stratejileri bakımından da önemli bir gerekliliktir. Zira yaşadıkları mekan, aynı zamanda yaptıkları enformel işlerin organizasyonunda büyük bir işlevi yerine getirmektedir. Katı atık toplayıcılığıyla uğraşan ailelerde, konut avluları, kağıt, plastik, hurda malzemelerinin ayrıştırıldığı ve geri dönüşüm fabrikalarına götürülmeden önce beklettikleri bir depo işlevi görmektedir. Bu nedenle bir konuta sahip olmak barınma ihtiyacının yanında bir geçim

\footnotetext{
2 Tuvalet, banyo ve mutfağın ortak kullanıldığı, her aile için bir odanın olduğu konut biçimidir.

3 Genel sağlık sigortasından prim ödemeden faydalanmak için yapılan gelir testinde, ailenin kişi başına düşen geliri asgari ücretin üçte birinden az olanlar yani aylık geliri yaklaşık 540 TL'nin
}

stratejisi alanı olarak da düşünülebilir (Akkan vd., 2011: 36$37)$.

Kiraladıkları konutlarda oturanların $(\% 25,7)$ çoğu ise, Çingene olmayan ailelerin bu mahallelere taşınmak istemediğini, bu nedenle ev sahiplerinin mecburiyetten evlerini kendilerine kiraladıklarını ifade etmişlerdir. Kiracı olmanın Çingeneler için yoksulluk, dışlanma gibi sorunları artırıcı etkisi yanında başka olumsuz etkileri de vardır. Gecekondu dahi denilemeyecek bu konutlarda, temiz su, tuvalet, banyo gibi temel ihtiyaçların bulunmadığı gözlenmiştir. Aylık kira bedelleri düşük olduğundan bu evler Çingeneler tarafindan tercih edilmektedir.

Nitekim görüşülen bir kadınının "Bu evde kim oturmak ister, bir çocuğumun sakatlık maaşı (300 TL) var. Başka gelirim yok. Bu evi de 125 TL'ye tuttum. Ne düzgün bir tuvaleti var ne de banyosu, içeride farelerle yaşlyoruz. Yine de inşallah bizi buradan çıkartmazlar, yoksa nereye gideriz. Bize (Domlar'a) kimse ev vermez. Yıkık, dökük, tek odalı da olsa bir evim olsaydl, böyle perişan olmazdlk." ifadeleri kiracılığın diğer yoksullardan farklı olarak Çingenelerde daha şiddetli deneyimlendiğini düşündürmektedir.

Genel olarak denilebilir ki, Çingeneler, elverişli mekânlardan yoksun bir halde yaşamlarını idame ettirmektedirler. Sağlık imkânlarından mahrum bu konutlarda yaşamaları ve bu yerleşim alanlarının "Çingene mahalleleri" olarak damgalanması, onların mevcut hallerinin devam edeceğini düşündürmektedir.

\subsection{Sosyal Güvence Durumu}

Çingenelerin yoksulluk ve dışlanma durumlarının anlaşılmasında, sosyal güvence durumu büyük öneme sahiptir. Örneklem grubunun sosyal güvence durumu Tablo 9'da yer almaktadır.

Tablo 9: Sosyal Güvence Durumu

\begin{tabular}{lcc}
\hline Sosyal Güvence & Sayı & $\%$ \\
\hline Hiçbir güvencem yok & 1 & $\mathbf{0 , 4}$ \\
SGK & 8 & $\mathbf{3 , 2}$ \\
Genel Sağlık Sigortası & 240 & $\mathbf{9 6 , 4}$ \\
\hline Toplam & $\mathbf{2 4 9}$ & $\mathbf{1 0 0}$ \\
\hline
\end{tabular}

Tablo 9'dan da anlaşılacağ1 üzere, örneklem grubunun \%3,2'si SGK'dan faydalanmakta iken, \%96,4'ü faydalanmamaktadır. Genel sağlık sigortası ${ }^{3}$, bireylerin gelir durumuna göre prim ödeyerek ya da hiç ödemeden yararlanabilecekleri bir sistemdir. Genel sağlık sigortasının Çingene aileler için, oldukça önemli fonksiyonları vardır. Zira yapılan sosyal yardımlar için referans teşkil eden bu sistem, sağlık ve sosyal yardımların alınmasında rol oynamaktadır.

Ancak araştırma alanında, prim ödeyerek genel sağlık sigortasından faydalanan 8 aileye rastlanmıştır. Geriye kalanların hemen hepsi, prim ödemeden bu sağlık sisteminden faydalanmaktadır. Yaptıkları işler çerçevesinde düşünülürse, gündelik işlerde ve diğer sektörlerde

altında olanlar herhangi bir prim ödemeden bu sistemden faydalanabilmektedir. Ancak emeklilik için genel sağlık sigortası geçerli değildir. 
güvencesiz çalış(tırıl)ma sorunu ortaya çıkmaktadır. Kent yaşamı içerisinde marjinal, enformel işlerle geçimlerini sağlayan Çingenelerin, ağır ve sağlıksız çalışma koşullarına güvencesizliğin de eklenmesi, onları olumsuz etkilemektedir.

Malatya'da yaşayan Çingenelere ait sosyal güvence verileri ile benzerlik taşıyan bir çalışmaya göre, Çingeneler arasında işsizlik oranının \%80-85 civarındadır. Görüşme yapılan kişilerden, sosyal güvenlik sistemine dâhil bir şekilde çalışanların oranının \%1-2 civarında olduğu sonucu ortaya çıkmıştır (Alp ve Taştan, 2011: 23).

Geçim stratejileri günü kurtarmaya ayarlı Çingeneler için en çok istenilen şey, güvenceli (SGK) bir işe sahip olmaktır. Ancak enformel ağlar, Çingenelere güvenceli iş imkanı sunma konusunda yetersiz kalmaktadır. Güvenceli bir işe duyulan özlemi araştırma alanındaki bir görüşmeci şu şekilde ifade etmiştir: "Çocuğum hasta, iyi ki yeşil kart verdiler. Bedava hastanelere gidiyoruz. Birkaç kez işe girdim ama iki ya da üç ay sonra çıkarıyorlar. Nedenini sorduğumuzda, işçi fazlalı̆̆ var diyorlar. Bizi işten attılar ona mı yanayım, çocuk hasta tekrar yeşil kart çıkarma işlemleri bir ay sürüyor, ona mi? Organize sanayi bölgesindeki fabrikalara başvuruyoruz. Iş̧ başvuru formunda referans istiyorlar, kimi göstereyim. Adres istiyor, zaten çoğu bu mahallenin ismini görünce hiç çă̆ırmıyor. Şimdi işe çağırdılar, sigortalı ama gitmeyeceğim, ya yine çıkarırlarsa, çocuk hasta haftalı kontrolleri var, tekrar yeşilkart çıkarana kadar ölür..." Bu bağlamda Çingenelerin iş, istihdam ilişkilerinde mekânsal damgalamanın da etkili olduğu sonucuna ulaşmak mümkündür. Çingenelerin yaşadıkları mekânsal damgalamanın emek piyasası ile ilişkileri noktasında Kempen (2002; Akkan vd., 2011: 52), istihdam ederken adrese dayalı ayrımcılığa dair yeterli veri olmamasına rağmen, bunun sıkça gündeme gelen bir fenomen olduğunu belirtmektedir. Malatya'da yaşadıkları mahallelerin, Çingene olmayanlar tarafından "Çingene mahallesi" olarak damgalanması, sadece Çingeneleri değil, diğer mahalle sakinlerini de olumsuz etkilemektedir.

Ayrıca sosyal sağlık güvencelerinin (yeşil kart) Çingeneler için önemli olduğu gerçeğine rağmen, bu sistemin birçok Çingene için istihdam olma isteklerini minimize ettiği söylenebilir. Yine, genel sağlık sigortasının, sadece sağlık ihtiyaçlarını karşılamaya yönelik olduğu ve gelecek için herhangi bir sosyal güvence (emeklilik) sağlamadığının bilincinde olmaları, geleceğe yönelik herhangi bir güvence planlarının olmadığına işaret etmektedir.

\subsection{Ortalama Aylık Gelir}

Ekonomik gelir düzeyi Çingenelerin nesnel ve öznel yaşam göstergelerini saptamada önemlidir. Örneklem grubundakilerin, hanelerine ait ortalama aylık gelirlerinin dağılımı Tablo 10'da yer almaktadır.

Tablo 10: Hanenin Ortalama Aylık Geliri

\begin{tabular}{lcc}
\hline Ortalama Aylık Gelir & Sayı & Geçerli \% \\
\hline Gelirim yok & 2 & $\mathbf{0 , 8}$ \\
$\mathbf{2 5 1 - 5 0 0 T L}$ & 28 & $\mathbf{1 1 , 2}$ \\
$\mathbf{5 0 1 - 7 5 0 T L}$ & 102 & $\mathbf{4 1}$ \\
$\mathbf{7 5 1 - 1 0 0 0 T L}$ & 97 & $\mathbf{3 9}$ \\
$\mathbf{1 0 0 1 T L}$ ve üstü & 20 & $\mathbf{8}$ \\
\hline Toplam & $\mathbf{2 4 9}$ & $\mathbf{1 0 0}$ \\
\hline
\end{tabular}

Tablo 10'da, tüm aile bireylerinin kazançları ve aldıkları yardım, kira geliri vb. hanenin toplam gelirine dâhil edilmiştir. Ancak ortalama aylık gelir hesapları, görüşülenlerin kendi beyanları olup, bazı görüşülenlerin gelirlerini daha düşük gösterme eğilimleri gözlenmiştir.

Tabloya göre, görüşülenlerin \%41'i hane gelirlerinin 501750 TL; \%39'u ise hane gelirlerinin 751-1000 TL olduğunu belirtmişlerdir. Görüşülenlerin genellikle vasıfsız inşaat işleri (boya, inşaat malzemeleri taşıma vs.), kavak kabuğu soyma, kavak doğrama, mevsimlik tarım işçiliği, hurdacılık, işportacılık, temizlikçilik, dilencilik, gibi işler yaptıkları görülmüştür. Ailede, başka çalışanların olması gelir oranlarını değiştirmektedir.

Ortalama aylık 251-500 TL geliri olanların (\%11,2), çoğu tek çalışanın bulunduğu hanelerdir. Ayrıca sakatlık maaşı alanlar ile yaşlılık maaşı alanlar da bu gelir grubunda yer almaktadır. Araştırma esnasında çoğu kez hamal pazarı, işçi çay ocakları vb. yerlerde, çalışamayan birçok kişiye rastlanmıştır. Ayda 6 ya da 7 gün çalıştıklarını ifade eden çoğu görüşmeci, aylık gelirlerinin 300-400 TL'yi geçmediğini iddia etmiştir.

Ortalama aylık geliri 1001 TL ve üstü olanlar (\%8), asgari ücretli çalışanlar ya da çok çalışanın olduğu hanelerdir. Bunlar arasında, sürekli bakıma muhtaç hastaları için sosyal hizmetlerden düzenli maaş alanlar da bulunmaktadır. Herhangi bir geliri olmayan $(0,8)$ yok denecek kadar azdir. $\mathrm{Bu}$ kişiler ise, sadece sosyal yardımlar ve hayırseverlerden aldıkları yardımlarla geçinenlerdir.

Bu bulgular doğrultusunda, Çingenelerin \%92'sinden fazlası açlık sınırında yaşamaktadır, denilebilir. Görüşülenlerin neredeyse tamamı, dört kişilik bir ailenin, sağlıklı, dengeli ve yeterli beslenebilmesi için gereken ortalama aylık gelire sahip değildirler.

Gelir konusunda doğru yanıtların alınması zor olduğundan, bu konu üzerinde önemle durulmuştur. Alt gelir gruplarına yönelik çalışmalarda, gelir konusunda hata yapma olasılığının yüksek olması nedeniyle, hanedeki bireylerin ne iş yaptıkları ve sosyal yardımlardan faydalanma durumları hakkında mahalle muhtarlarından ve haneye yakın esnaflardan bilgiler alınmıştır. Ayrıca ekonomik gelir düzeyini doğrulamak amacıyla ihtiyaç ve harcama durumları ele alınmıştır.

\section{8. İhtiyaç ve Harcama}

İhtiyaca göre harcama, Çingenelerin gelir düzeyleri hakkında ipuçları sunmaktadır. Örneklem grubunun gelirlerini en fazla harcadığı ihtiyaçların dağılımı aşağıdaki tabloda yer almaktadir.

Tablo 11: Gelirin En Fazla Harcandığı İhtiyaçlar

\begin{tabular}{lcc}
\hline İhtiyaçlar & Sayı & \% \\
\hline Eğitim & 15 & $\mathbf{6}$ \\
Sağlık & 2 & $\mathbf{0 , 8}$ \\
Gıda & 221 & $\mathbf{8 8 , 8}$ \\
Kira & 11 & $\mathbf{4 , 4}$ \\
\hline Toplam & $\mathbf{2 4 9}$ & $\mathbf{1 0 0}$ \\
\hline
\end{tabular}

Tabloya göre, en fazla harcama $(\% 88,8)$ beslenme/gida maddeleri alanındadır. Çingenelerin ekonomik yetersizlikleri ve düzensiz işleri ihtiyaç ve harcama eğilimlerine etki etmektedir. Sınıfsal eşitsizlikleri giderebilecek fonksiyonu olan eğitim harcamaları (\%6) yok 
denebilecek kadar azdır. Görüşmecilerden birinin, “48 yaşındayım, varsa yoksa karın doyurmak, ne bir birikimim var ne de çocuklarımı okutacak durumum. Çocuğum bu yıl dershaneye gideyim dedi, ama gönderemedim, okuldan alıp berberin yanına çırak verdim." ifadeleri, ekonomik yetersizliklerinden dolayı eğitime harcama yapamadıklarını göstermektedir.

Görüşmeler sırasında telaffuz ettikleri, "Çocuklardan gizli markete giderim, beraber gidersek bir şeyler istiyorlar, ben çayl, şekeri, yağl zor alıyorum”, "Gaco (Çingene olmayan) ne yapsa da bizim gibi fakir kalmaz, çünkü zenginler de "Gaco", onlar hep Gacolara yardım eder bizi kim ne yapsın”, "biz de Gacolar gibi çocuklarımızı güzel okullara göndermek isteriz, ama ne hikmetse her şeyin en iyisi Gacolarda, sonra da hirsılık yaptın falan derler, ne yapalım." gibi ifadeler, gelir düzeylerinin, yoksulluklarının, tüketimdeki konumlarının ve tasarruf eğilimlerinin, anlaşılmasında önemlidir. Dışlanmışlık, çaresizlik gibi duyguları yaşayan görüşmeciler, yoksunluklarını Çingene olmayanlara bağlamaktadırlar.

Dolayısıyla, Çingenelerin tüketim biçimlerini, düzensiz ve düşük gelir düzeyi biçimlendirmektedir. Geçmişte esnek iş alanlarından ve günübirlik yaşam tarzlarından kaynaklanan ihtiyaç ve harcamalarını belirleyen habitusları, ekonomik imkânlarının olmamasından, günümüzde de yeni kuşakların ihtiyaç ve harcama özellikleriyle kısmen benzerlik taşımaktadır (Bourdieu, 2006: 182).

\section{9. İş/Uğraş Alanları ve Geçinme Stratejileri}

Bireyin, hayatını sürdürebilmesi ve yaşam kalitesini arttırabilmesi ekonomik gelirine bağlıdır. Çingenelerin geçimlerini sağladıkları işılerin dağılımı Tablo 12'de yer almaktadir.

Tablo 12: İş/Uğraş Alanları

\begin{tabular}{lcc}
\hline Geçimin Sağlandığı İş & S & \% \\
\hline Aldığım yardımlarla & 38 & $\mathbf{1 5 , 3}$ \\
Irgatlık/Rençberlik & 3 & $\mathbf{1 , 2}$ \\
Nakliyecilik & 1 & $\mathbf{0 , 4}$ \\
Hurdacılık & 12 & $\mathbf{4 , 8}$ \\
Hamalık & 9 & $\mathbf{3 , 6}$ \\
Ayakkabı boyacılığı & 3 & $\mathbf{1 , 2}$ \\
Seyyar satıcılık & 8 & $\mathbf{3 , 2}$ \\
İşportacılık & 25 & $\mathbf{1 0}$ \\
Gündelikçi/Mevsimlik işçi & 86 & $\mathbf{3 4 , 5}$ \\
Müzisyenlik & 3 & $\mathbf{1 , 2}$ \\
Kalaycılık & 3 & $\mathbf{1 , 2}$ \\
Çobanlık & 4 & $\mathbf{1 , 6}$ \\
Kağıt toplayıcılığı & 12 & $\mathbf{4 , 8}$ \\
Falcılık & 3 & $\mathbf{1 , 2}$ \\
Elekçilik & 3 & $\mathbf{1 , 2}$ \\
Bohçacılık & 34 & $\mathbf{1 3 , 7}$ \\
Diğer & 2 & $\mathbf{0 , 8}$ \\
\hline Toplam & $\mathbf{2 4 9}$ & $\mathbf{1 0 0}$ \\
\hline
\end{tabular}

Tablo 12'ye göre, görüşülenlerin \%34,5'i gündelik/mevsimlik işçi statüsünde geçimini sağlamaktadır. Bunu sırasıyla, aldığı yardımlarla $(\% 15,3)$; bohçacılıkla $(\% 13,7)$; işportacılıkla $(\% 10)$; kâğıt-hurda toplayıcılığıyla $(\% 4,8)$; hamallıkla $(\% 3,6)$ ve seyyar satıcılıkla $(\% 3,2)$ geçimini sağlayanlar takip etmektedir.

Gündelik/mevsimlik işlerle uğraşanlar, çok düşük ücretle çalıştıklarını ve nadiren iş bulabildiklerini beyan etmişlerdir.
Gündelik işler, erkekler için vasıffsız inşaat işleri (boya, inşaat malzemeleri taşıma vs.), kavak kabuğu soyma, kavak doğrama, mevsimlik tarım işçiliği, gibi işlerden, kadınlar için ise temizlikçilik, kayısı çekirdeği seçiciliği ve mevsimlik tarım işçiliği gibi işlerden oluşmaktadır.

İşsiz olup olmadan vakıf ve kamu (valilik, belediye vs.) kurumlarından aldıkları yardımlarla geçinenler $(\% 15,3)$, genellikle yaşlı veya çalışamayacak durumda olanlardır.

Bahçeli konutların yoğun olduğu mahallede, kağıt/hurda toplayıcılığı diğer bir iş koludur. Ayrıca görüşmeler esnasında, yaptıkları işlerle ilgili sorulara samimi cevap vermeyen katılımcılara da rastlanmıştır. Özellikle dilencilik yapan kadın katılımcılar, aslında bohçacılık yaptıklarını iddia etmişlerdir.

Göçer yaşam tarzından konar-göçerliğe, konar-göçerlikten yerleşikliğe doğru değişen yaşam tarzları, Çingenelerin çalışma yaşamlarında radikal bir dönüşüme neden olmuştur. Son yıllarda gelişen sanayi sektörü ile birlikte geleneksel mesleklerini kaybeden Çingeneler, kentlerin kenar bölgelerinde yarı yerleşiklik ya da yerleşik yaşam tarzlarının dayattığı marjinal işlere yönelmek zorunda kalmışlardır. Yeni mesleklerin ediniminde gerekli niteliklere sahip olmamaları, kentlerde geçici/güvencesiz çalışmaya mecbur olmalarına yol açmıştır.

Malatya'nın kenar mahallelerinde ve kent merkezine yakın yerlerde konumlanan Çingenelere, iş, istihdam ve güvence üçgeninde bakılacak olunursa, yaşamlarını idame ettirmek için yerleşik toplumsal önyargılarla da mücadele eden, iş bulmak için sürekli mekân değiştiren, vasıfsız ve ağır/tehlikeli işlerde çalışan Çingeneler, geçimlerini temin etmede zorlanmaktadırlar. Çok çalışmalarına rağmen temel ihtiyaçlarını bile karşılayamamaktadırlar.

Öte yandan, etnik grupların ya da etnik azınlıkların, iş piyasasına girmelerinde önemli engellerin olduğu yaygın kabul görmektedir (Bkz. Standing, 2014: 150; Can, 2007; Y1lgür, 2012; Akkan vd. 2011; Marsh, 2008). Örneğin, etnik grupların marjinal işlere yöneliminin nedenleri üzerine çalışmalar yapan Wilson, bu grupların; farklı bireysel donanımları, var olan işgücü piyasası alışkanlıklarına benzer olmayan yapısal özellikleri ve işe alınırken maruz kaldıkları ayrımcılık nedeniyle enformel işgücü piyasalarındaki enformel işlerde yoğun olarak çalıştıkları saptamasında bulunmuştur (2003: 429). Ancak ayrımcılığın doğrudan iş alanına yansımasının yanında, başka alanlarda yapılan ayrımcılığın da dolaylı yollardan iş/meslek edinmede olumsuz etkileri olduğu göz ardı edilmemelidir. Eğitim ve diğer alanlarda ayrımcılığa maruz kalan Çingeneler, hayatlarının diğer safhalarında da ayrımcılıkla karşılaşmaktadırlar. İşsiz ya da marjinal sektörlerdeki görüşmecilerin, bu işlere neden yöneldiğine dair hikayelerinde, düzenli işlerden uzak kalmalarında eğitim yıllarında uğradıkları ayrımcılık ve Çingene oldukları için çırak-kalfa olarak çalıştırılmama gibi faktörlerin de etkili olduğunu düşündürmektedir.

Tablodaki veriler, Türkiye'deki raporlarla benzerlik taşımaktadır. Örneğin, Türkiye'de Romanların Durumu Türkiye'de Çalışma ve İnsana Yakışır İş Koşulları Sorunları Aralık 2010 raporuna göre; Türkiye'de bulunan Çingene topluluklarının, istihdama erişimde çok önemli engellerle karşılaştıkları tespit edilmiştir. Antakya, Çorlu ve Bartın'da katılımcıların tamamına yakını, işsizliğin kendi toplulukları 
için en ciddi problem olduğunu belirtmişlerdir. Her üç bölgede de Çingenelerin büyük çoğunluğunun, resmi olarak işsiz oldukları rapor edilmiştir: Antakya'da Dom ve Çorlu'da Roman topluluğu içerisinde işsizliğin \%90'ın üzerinde olduğu tahmin edilmektedir. Bartın'da yapılan araştırmanın sonuçlarına göre, topluluğun tamamına yakınının işsiz olduğu ortaya çıkmıştır (FSG, 2010: 18).

Öte yandan, Çingene kadınları, erkeklere oranla daha geçici ve güvencesiz işlerde çalışmaktadırlar. Mesleki formasyon gerektirmeyen bu işler, kadınların meslek hayatına dahil olamamasının en önemli nedenleri arasındadır. Çingene usulü mesleklerin işlevsel olduğu dönemlerde, kadınların mesleki yeteneklerinin en az erkekler kadar olduğu, buna karşın genellikle endüstriyel beceri gerektiren modern mesleklere dâhil olmadıkları düşünülebilir.

Yapılan birçok araştırmada, Çingeneler iş bulma konusunda etnik kökenleri nedeni ile dezavantajlar yaşamakta, iş olanaklarına erişimleri zorlaşmaktadır. Çingene gruplarında etnik ayrımcılığın/dışlamanın iş alanındaki yaygınlığına Malatya'da yaşayan Çingenelerde de sıkça rastlanılmıştır. Görüşmecilerden birinin, "Uzun bir süreden sonra Dom olduğumu gizleyerek bir petrol ofisinde pompacı olarak işe başladım. $\ddot{U} c ̧$ ay boyunca diğer pompacılarla birlikte muhasebeciye günlük hesap veriyorduk. Ben bir kuruş açık vermedim. Nasil ki Dom olduğumu ögrenmişler patron beni işten attı. Nasıl ögrenmiş, diye merak ettim. Orada ki arkadaşlarımın söylediğine göre, mahallemden Dom olmayan biri beni görmüş ve bu Çingene diye patrona söylemiş. Şimdi ise bir asfalt şantiyesinde şoförlük yapıyorum. Öğrenmesinler diye çarşıda yürürken Dom olanlarla konuşmuyorum, kuzenimle, kardeşimle. Bunun acısını kimse bilemez. " ifadeleri, aslında Çingenelerin maruz kaldıkları çok boyutlu dışlamanın kendileri için işsizliğe de neden olabildiğini göstermektedir.

Pek çok araştırmada sosyal dışlanma, doğrudan işsizlik ile ilişkilendirilmektedir. Görüşülen birçok kişi, işsizliğin hem kendisi hem de ailesi için olumsuz sonuçlar doğurduğunu ifade etmiştir. Ayrıca, işsizlik nedeniyle ekonomik mahrumiyetin yanısıra onuruna, özsaygısına ve özgüvenine yönelen türlü olumsuzluklar, sembolik şiddetin varlığına işaret etmektedir. Sennett (1972)'in de vurguladığı üzere, bu tür sınıfsal ayrımların ve bu ayrımlara eşlik eden içsel ve dışsal sembolik şiddetin karakterler üzerinde açtığı yaralar sebebiyle kişilerin yaşadığı eziklik, değersizlik hissi, özsaygı yitimi ve diğer karakter bozuklukları ortaya çıkmaktadır. Dolayısıyla, Çingenelerin, işsizlik nedeniyle endişe, karamsarlık, aile yaşamında çözülmeler, sosyal kültürel değerlerde gerileme, içinde bulunduğu toplumdan uzaklaşma gibi dişlanmaya yol açan pek çok sorunla da karşılaştığ 1 düşünülmektedir.

Kimliklerinden kaynaklanan önyargılar, Çingene gruplarının ekonomik faaliyetlerde, dezavantajlı konumlarını açıklayacak başka bir faktördür. Bireylerin ait olduğu gruba yönelik önyargılar, formel iş alanlarında istihdamlarını etkilemekle kalmayıp, orta düzeyli enformel iş alanlarındaki faaliyetlerde de bir dizi sorunlarla karşılaşmalarına yol açmaktadır. Örneğin, esnaf olmak isteyen birçok görüşmeci, grup kimliğinden dolayı, tüketicilerin kendilerini tercih etmeyecekleri kaygısıyla bu isteklerini/amaçlarını gerçekleştirememektedir.
Bu bulgular 1şığında, kendilerine özgü mesleklerinin yok oluşu, onları ekonomik olarak olumsuz etkilemiştir. Tarihsel süreçte Malatya'da yaşayan Çingenelerin mesleki formasyonlarının köklü değişimi, vasıf gerektiren işlerde değil, Çingene olmayanların yapmak istemediği, düşük prestijli ve tehlikeli/riskli işlerde yoğunlaşmalarına neden olmuştur.

\subsection{Yoksulluk Nedenleri}

Yoksulluk, genel anlamıla, ekonomik, politik ve kültürel mahrumiyet durumunu ifade eden bir olgudur. Bu bağlamda işsizlik, vasıfsızlık, engellilik, etnik kimlik gibi faktörler yoksulluk nedenleri arasında önemli bir yere sahiptir. Örneklem grubunun yoksulluk nedenlerinin dağılımı Tablo 13 'te yer almaktadir.

Tablo 13: Yoksulluk Nedenleri

\begin{tabular}{lcc}
\hline Yoksulluklarının Nedeni & Sayı & $\mathbf{\%}$ \\
\hline Yoksul değilim & 4 & $\mathbf{1 , 6}$ \\
Engelli/hasta olmak & 3 & $\mathbf{1 , 2}$ \\
Vasıfsız olmak & 29 & $\mathbf{1 1 , 6}$ \\
Çingene olmak & 211 & $\mathbf{8 4 , 7}$ \\
Diğer & 2 & $\mathbf{0 , 8}$ \\
\hline Toplam & $\mathbf{2 4 9}$ & $\mathbf{1 0 0}$ \\
\hline Tabloya göre, örneklem & grubunun & $\%$ \% 84,7 'si,
\end{tabular}
yoksulluklarının nedeni olarak Çingeneliklerini göstermişlerdir. Görüşmelerde Çingene oldukları için ekonomik hayattan dışlandıklarını beyan edenler, bu nedenle iş bulamadıklarını belirtmişlerdir. Yapılan ikili görüşmelerdeki, "Bir iş sahibi olmak herkesin isteyeceği bir şey ama ben kaç iş değiştirdim bilmiyorum, ne zaman işe başlasam "Dom” olduğumu öğrendikleri an çıkarıorlar, şimdi bir senedir işsizim, "Dom” olmasam işsiz de olmazdım." ifadeler, Çingeneliklerinin, iş yaşamlarını olumsuz etkilediğini ve bu durumun yoksulluğa neden olduğunu göstermektedir.

Görüşmecilere yoksulluk nedenleriyle ilgili sorular sorulduğunda, "Niye Gacolar da yoksul yok, onların yoksullarl bile bizden zengin.”, "Bana burada bir tane zengin Çingene göster, zengin olanlar var ama onlar da bizi tanımıyor ki artık...", "Bizde zengin olan Gacolaşıyor." yönündeki cevaplar, yoksul olmak ve Çingene olmak arasındaki ilişki algılarına işaret etmektedir. $\mathrm{Bu}$ ifadeler, yoksulluklarının Çingenelikten kaynaklandığına koşulsuz olarak inandıklarını göstermektedir. Ayrıca bu cevaplar yoksulluktan öte yersizlik-yurtsuzluk, çok boyutlu dişlama ve damgalama süreçlerini imleyen bir durum olarak da değerlendirilebilir.

Yoksullukla etnik köken arasında bir ilişki bulunmadığını belirtenlerin aksine Can, yoksul mahallelerde, özellikle Çingenelerle ilgili katı dışlayıcı tutumun büyük ölçüde geçerliliğini sürdürdüğü görüşündedir (2007: 193). Bu katı dışlayıcı tutum, yoksulluklarının nedeni olarak "Çingene" olmalarını ön plana çıkarmakta ve sembolik şiddetin Çingenelerce deneyimlemesine yol açmaktadır.

Tabloda, görüşülenlerin \%11,6'sı, yoksulluklarının nedeni olarak vasıfsızlığı görmektedir. Çingenelerde vasıfsızlık, Çingene usulü mesleklerin yok olması, konar-göçerlikten dolayı sürekli düzenli çalışamama gibi durumlardan kaynaklanmaktadır. Yoksulluklarını sanayi toplumuna geçişle birlikte, Çingene usulü mesleklerin kaybolmasına ve bu çerçevede vasıfsılzlaşmalarına bağlayan bir görüşmecinin 
"Çok kazançlı işlerimiz vardl; elekçilik, sepetçilik, kalaycılık, bunlar bizden sorulurdu, ama şimdi hiç biri yok." sözleri, teknolojik gelişmelerle birlikte, Çingene usulü mesleklerin kaybolmasının/azalmasının onları yoksullaştırdığına işaret etmektedir.

Araştırma alanını oluşturan mahalleler, etniklik, sınıf altı ve genelde göçmenlerden oluşan alanlar olarak da değerlendirilebilir. Görüşmelerde Çingenelerin sosyal dişlanma biçimleri, yoksullukla birlikte istihdamdan dışlanma, sosyal yalıtım, eşitsiz eğitim firsatları, kamusal alandan dişlanma (Önen, 2011: 468) gibi dezavatajlara da yol açmaktadır. Çingenelerin yoğunluklu yaşadıkları bu mahallerde, yaşamanın getirdiği mekânsal damgalama ile Çingenelik, toplumda yoksulluğun ve sosyal dışlanmanın statüsü olarak karşımıza çıkmaktadır (Akkan vd.2014: 115).

Araştırma alanı, geçmişte olduğu gibi günümüzde de düşük gelirli insanların tercih ettiği yerleşim alanlarından oluşmaktadır. Bazı mahalleler geçmişten itibaren şehre yerleşmek veya çalışmak için kent dışından ya da kentin ilçelerinden gelen insanların ilk uğrak yeri olma özelliğini sürdürmektedir. Mahalledeki insanların büyük çoğunluğunun en önemli ortak noktası yoksul olmalarıdır. $\mathrm{Bu}$ nedenle mahalle, yoksulluğun Çingenelikle örtüştürüldüğü bir örneği de temsil etmektedir. Zira bu mahallelerde oturan ve Çingene olmayan yoksulların iş başvurularında, ikametlerinden ötürü Çingene olarak algılandıklarını belirtenlere sıklıkla rastlanmıştır. Özellikle mahallede bazı Güneydoğu illerinden göç edenlere yönelik bu tür damgalamalar, buralarda (Wacquant, 2011: 38) işsizliğin yoğun olmasında etkili olmuştur. Bu alanların etnik kimlikle (Çingene) özdeşleşmesi, ekonomik faaliyetlerin dar bir alana hapsolmasina neden olmakta ve en temel ihtiyaçların dahi karşılanmasını zorlaştırmaktadır. Bu nedenle Çingenelerin ve Çingene olmayanların beraber yaşadıkları bu mekânların Çingenelikle özdeşleştirilmesi ve Çingenelerin, Çingeneliklerinden kaynaklanan dar ekonomik alanları düşünüldüğünde, "yoksulluğun Çingeneleşmesi” kavramının Çingenelerdeki yoksulluğu betimlemekte işlevsel olduğu düşünülebilir.

\subsection{Sosyal Yardımlardan Faydalanma Durumu}

Sosyal yardımlar, geliri düzensiz Çingeneler için son derece önemlidir. Örneklem grubundakilerin yardım aldığı yerler aşağıdaki tabloda yer almaktadır.

Tablo 14: Örneklem Grubunun Yardım Aldığı Yerler

\begin{tabular}{lcc}
\hline Yardımın Nereden Alındığı & Sayı & $\mathbf{\%}$ \\
\hline Almıyorum & 107 & $\mathbf{4 3}$ \\
Valilik/Belediye & 123 & $\mathbf{4 9 , 4}$ \\
Vakıf/Dernekler & 8 & $\mathbf{3 , 2}$ \\
Hayırseverler & 11 & $\mathbf{4 , 4}$ \\
\hline Toplam & $\mathbf{2 4 9}$ & $\mathbf{1 0 0}$ \\
\hline
\end{tabular}

Tablo 14'e göre, Çingeneler genel olarak valilik/belediye $(\% 49,4)$ 'den yardım almaktadırlar. Yardım alanlar, örneklem grubunun \%57'sine tekabül etmektedir.

Valilikten alınan sosyal yardımlar; Sosyal Yardımlaşma ve Dayanışma Vakfı (SYDV), Sosyal Hizmetler Kurumu gibi birçok kurum ve kuruluştan alınmaktadır. Ancak görüşmelerde daha çok SYDV ve Sosyal Hizmetler Kurumundan yardım aldıkları anlaşılmıştır. Bu bağlamda, SYDV'den alınan yardımlar; kömür, gıda, nakit para, sağlıksız konutlar için ev tadilat ücreti, eğitim bursu, çocuk parası gibi kalemlerden oluşmaktadır. Sosyal Hizmetler Kurumundan alınan yardımlar ise; bakıma muhtaçlar için bakım ücreti, doğum ücreti gibi kalemleri kapsamaktadır. Dolayısıyla alınan yardımların büyük çoğunluğunun kamu kurum ve kuruluşlarından olması, Çingenelerin devletle olan ilişkilerinin olumlu yönde seyrettiğini göstermektedir.

Tabloya göre, görüşülenlerin $\% 43$ 'ü yardım almamaktadır. Bunların çoğu yardım için gerekli koşullara sahip olmayanlardır. Zira barakalarda yaşadıkları için yardım alamamaktadırlar. Bunlar hukuki açıdan, barakanın bulunduğu ana haneye yardım yapıldığını ve bu barakaların belediyeye kayıtlı olmadığı için yardımlardan faydalanamadıklarını belirtmişlerdir.

Görüşmelerde az da olsa Çingene olduğu için yardım alamadıklarını belirtenler de olmuştur. Yapılan enformel görüşmelerde, bunların büyük çoğunluğunun yardım için gerekli koşulları taşımadıkları görülmüştür. Yardım alamamalarının nedeni olarak Çingeneliği gerekçe göstermeleri, dişlanma, sahipsizlik, kimsesizlik, kendini madun gösterme çabasına bağlanabilir. Görüşmecilerin çoğu, sosyal yardımlara nasıl ulaşacaklarını bilmediklerini de sık sık dile getirmişlerdir. Önen (2011: 474-475)'in yaptığı araştırmaya göre, Türkiye'nin Batı kesimlerinde yaşayan Romanlar, Domlara göre sosyal yardımlara ve sosyal hizmetlere daha fazla ulaşabilmektedir. Romanların sosyal yardım ve hizmetlere ulaşmalarında Edirne Roman Derneği etkin rol oynamaktadır. Romanlar Edirne'deki SYDV'dan yoğun bir şekilde faydalanırken, Domlar SYDV'na nasıl ulaşacaklarını ve kaynaklardan nasıl faydalanacaklarını bilememektedirler. $\mathrm{Bu}$ durum, kaynaklara ulaşmada örgütlülüğün önemini ortaya koymaktadir.

\subsection{Dışlanma Alanları}

Çingenelerin toplumsal konumlarının anlaşılmasında dışlanma faktörü önem taşımaktadır. Ayrıca Çingenelerin nerelerden dışlandıklarının, kendi dünyalarından, kendi gözlerinden ortaya konulması da önemlidir. Örneklem grubunun nerelerden dışlandıklarının dağılımı Tablo 16'da yer almaktadır.

Tablo 16: Çingenelikten Dolayı Dışlandıkları Alanlar

\begin{tabular}{lcc}
\hline Dıșlanma Alanları & Sayı & $\mathbf{\%}$ \\
\hline Hayır dışlanmadım & 6 & $\mathbf{2 , 4}$ \\
Mahalleden & 171 & $\mathbf{6 8 , 7}$ \\
Okuldan & 9 & $\mathbf{3 , 6}$ \\
İs yerinden & 31 & $\mathbf{1 2 , 4}$ \\
İbadethanelerden & 3 & $\mathbf{1 , 2}$ \\
Alışveriş merkezlerinden & 3 & $\mathbf{1 , 2}$ \\
Resmi kurumlardan & 26 & $\mathbf{1 0 , 4}$ \\
\hline Toplam & $\mathbf{2 4 9}$ & $\mathbf{1 0 0}$ \\
\hline
\end{tabular}

Tablo 16'ya göre, görüşülenlerin sadece $\% 2,4$ 'ü herhangi bir yerden dışlanmadıklarını beyan etmişlerdir. Buna karşılık \%97,6'sı bir biçimde dışlandıklarını söylemişledir.

Çingene olduğu için dışlandıklarını söyleyenlerin çoğu $(\% 68,7)$, mahalleden dışlandıklarını belirtmişlerdir. Bunu, Çingene olduğu için iş yerinden $(\% 12,4)$, resmi kurumlardan $(\% 10,4)$, okuldan $(\% 3,6)$, ibadethanelerden, $(\% 1,2)$ ve AVM'lerden $(\% 1,2)$ dişlananlar takip etmektedir. 
İkamet ettikleri mahalleden dışlandıklarını söyleyenler, Çingene olmayan komşuları tarafından dışlananlardır. Bu konuda görüşmecilerin, "Onlar bizi beğenmez, kapılarını bize açmazlar, bizi görünce başlarını çevirirler.”, "Bizim komşularımıza hiçbir zararımız olmamıştır, bizle neden konuşmazlar, bizi neden hakir görürler anlamış değilim.", "Mahalleden bir yere gidecek olsam esnafin kapisindan geçmek istemiyorum, selamımı dahi zorla alıyorlar. ” sözleri, mahallede sosyal dışlanmanın şiddetli bir biçimde yaşandığını düşündürmektedir. Ayrıca bu ifadelerde, ikamet ettikleri mahalleden dişlanmaları, yok sayılmaları sonucu Çingenelerde acı, öfke, manevi yoksunluk, sosyal kapanma, sosyal mesafe gibi sorunların yaşandığını düşündürmektedir. Çingene olmayanlar tarafından "istenmeyen", "mesafeli durulması gereken" olarak dışlanan Çingeneler, onurlarının zedelendiğini dile getirmişlerdir.

Çingene oldukları için iş yerinden dışlandıklarını söyleyenler $(\% 12,4)$, bu durumun bir yandan onurlarını zedelerken, diğer yandan ekonomik sıkıntılara ve giderek yoksulluğa neden olduğunu belirtmişlerdir. Enformel görüşmelerde görüşmecilerin çoğu, düzenli bir işte çalışamamalarını Çingeneliklerine bağlamışlardır. Yeni bir işe girseler dahi Çingene oldukları öğrenildiğinde, dışlanmaya, mobbinge maruz kaldıklarını dile getirmişlerdir.

Çingeneliklerinden dolayı resmi kurumlardan dışlananlar (\%10,4), kamu hizmetlerinden mahrum kaldıklarını, devletin başka yoksullara yaptığı yardımlardan yararlanamadıklarını belirtmişlerdir. Görüşülenler ikamet adreslerinden dolayı Çingene olduklarının anlaşıldığını ve dışlamalara maruz kaldıklarını beyan etmişlerdir.

Okuldan dişlandıklarını belirtenler $(\% 3,6)$, bu durumu eğitimlerini yarıda bırakmalarının en büyük nedeni olarak görmektedir. İbadethanelerden dıșlandıklarını $(\% 1,2)$ beyan edenler ise, hem camilerden hem de cem evlerinden dışlandıklarını dile getirmişlerdir.

Görüşmelerde, Çingene olmayanları beğenmeyenler, kendilerini daha temiz addedenler ve onların daha aşağı olduğunu belirtenlere de rastlanmıştır. $\mathrm{Bu}$ durum, dışlanmaya verilen tepkiyi göstermektedir. Maruz kaldıkları çeşitli dişlamalar nedeniyle "Gaco"yu dişlamak, beğenmemek, küçük görmek karşılıklı dışlamanın olduğunu göstermektedir. Ayrıca temiz olma durumu ile de kendilerine yakıştırılan "pis" damgasının doğru olmadığını ispatlama çabasında oldukları gözlenmiştir.

Akkan vd.'nin 2007'de Zonguldak, Çanakkale, Batman, Mardin (Nusaybin) illerinde, Çingene mahallelerinde gerçekleştirdikleri çalışmaya göre, Çingenelerin durumunun çok boyutlu bir sosyal dişlanma sürecine işaret ettiği tespit edilmiştir. Çingenelerin sosyal dışlanma süreçlerinin, mekânsallıklarıyla, marjinallikleriyle, derin yoksulluklarıyla ve güvencesiz geçim süreçleriyle yakın bir ilişkisi olduğunu ileri süren Akkan vd., Çingeneliğin dışlanma süreçlerine eklemlenmesiyle sosyal dışlanmanın daha derin bir hal aldığını ve Çingenelerin toplumdan kopuk bir hayat yaşadıklarını belirtmiştir (radikal.com.tr, 2007).

Dolayısıyla Çingeneliğin yol açtığı dışlamalar, Çingenelerin yaşamlarının hemen her alanına yansımaktadır. Gerek sosyokültürel gerek sosyo-ekonomik gerekse de diğer alanlarda dezavantajlı toplumsal konumlarına sebebiyet vermektedir. Çeşitli alanlarda dişlanmaya maruz kalma durumu, Çingenelerin yoksulluğa mahkûm bir durumda yaşamalarına, grupları dışındakilerle sosyal etkileşimlerinin zayıf olmasına ve sosyal bağların ortadan kalkmasına yol açmaktadır.

\subsection{Dışlanmalarında Çingenelerin Payı}

Sosyal dışlanmanın nedenlerinden biri de toplumsal normlara uymamalarıdır. Toplumsal normlara uymama çeşitli yaptırımlar gerektirmektedir. Bu yaptırımlar dışlama, yalnızlaştırma gibi süreçleri kapsamaktadır. Çingenelerin dışlanmalarında kendi rollerinin ne olduğuna ilişkin görüşlerinin dağılımı Tablo 17'de yer almaktadır.

Tablo 17: Dışlanmada Çingenelerin Rolü

\begin{tabular}{|c|c|c|}
\hline Dışlanmada Çingenelerin Rolü & Sayı & $\%$ \\
\hline Hayır & 4 & 1,6 \\
\hline $\begin{array}{l}\text { Bazı Çingenelerin toplumca olumsuz kabul } \\
\text { edilen davranışlar sergilemeleri ve suç } \\
\text { işlemeleri Çingenelerin imajını olumsuz } \\
\text { etkiliyor }\end{array}$ & 165 & 66,3 \\
\hline $\begin{array}{l}\text { Bazı Çingenelerin dilencilik yapmaları } \\
\text { bizim dışlanmamıza yol açıyor }\end{array}$ & 57 & 22,9 \\
\hline Hiç düşünmedim & 23 & 9,2 \\
\hline Toplam & 249 & 100 \\
\hline
\end{tabular}

Tabloda, görüşülenlerin büyük çoğunluğu $(\% 66,3)$, bazı Çingenelerin toplumca olumsuz kabul edilen davranışlar sergilemelerinin ve suç işlemelerinin Çingenelerin imajını olumsuz etkilediği bu nedenle de dişlandıkları yanıtını vermiştir. Görüşülenlerin \%22,9'u dışlanmalarının nedeni olarak bazı Çingenelerin dilencilik yapmalarını göstermiştir. Böylece Çingenelerin dışlanmalarının sorumluluğunu yine Çingenelere yükleyenlerin toplam oranı \%89,2'ye ulaşmıştır.

Bazı Çingenelerin toplumca olumsuz kabul edilen davranışlar sergilemelerinden ve suç işlemelerinden Çingene imajının olumsuz etkilendiğini beyan edenler, sorunun temel kaynağının Çingeneler içerisinde sosyal düzene aykırı davrananlar olduğunu ve bu durumun kendilerini olumsuz etkilediğini düşünmektedirler. Çingene kimliğinin olumsuz imajlarla örülü olmasında; Çingenelerin sosyal düzene uygun hareket etmemeleri, suç işlemeleri (hırsızlık) gibi nedenler etkili olmaktadır. Enformel görüşmelerde, “ Çingeneler rahat durmuyor, ya hirsızllk ediyorlar, ya da başka suçlar işliyorlar." gibi ifadeler Çingene imajının olumsuz etkilenmesinde ve bu nedenle dişlanmalarında, sorumluluğun Çingenelere yüklendiğini göstermektedir.

Aynı şekilde, bazı Çingenelerin dilencilik yapmalarının, dışlanmalarına neden olduğunu belirtenler, bu durumun alışkanlık haline geldiğini ve yeni nesillere model olduğunu savunmaktadırlar. Görüşülenlerin “ Taşı sıksa suyunu çıkarır, ancak gidip dilenenler bizde çok...", "Çingene dilenciler bizim adımızı batırıyor.", "Komşumuzun durumu iyi evinde çalışanı var ama yine de dileniyor, işte bunlar bizim adımızı kötüye çıkarıyor." sözleri, dışlanmalarında Çingenelerin rolünün bulunduğunu düşündüklerini göstermektedir.

Dolayısıyla Çingenelerin dışlanmalarının sorumluluğunu yine Çingenelere yükleyenlerin büyük çoğunlukta $(\% 89,2)$ olduğu görülmektedir. Kendi ifadeleriyle Çingenelerin toplumsal düzene uygun davranmamaları, suç işlemeleri, dilenciliği geçim stratejisi haline getirmeleri Çingene imajını olumsuz etkilemekte ve dişlanmalarına neden olmaktadır. 
$\mathrm{Bu}$ ifadeler Çingenelerin aynı zamanda özeleştiri yaptıklarının da bir göstergesidir.

\section{Sonuç}

Çingeneler, yaşadıkları toplumlarda yaşam biçimleri, davranış şekilleri, fiziksel özellikleri, kapalılıkları ile kendilerine kuşku ve merakla bakılan konumunda olagelmişlerdir. Haklarında ortaya atılan anlatılar, mitler vs. Çingenelerin hemen hemen tüm ülkelerde "toplumsal sorun" ve "tehlikeli insanlar" olarak görülmelerine neden olmuştur. $\mathrm{Bu}$ nedenle sürekli reddedilmiş ve türlü türlü dışlama biçimlerine maruz kalmışlardır.

Malatya'da yaşayan Çingenelerde yoksulluk ve sosyal dışlanmaya odaklanan bu çalışmaya göre, Çingenelerin öğrenim düzeyleri düşüktür. Çingenelerin büyük çoğunluğu, Malatya'ya çok önceden göç etmiş ya da Malatya doğumludur. Göçle gelenler işsizlik, kan davası, evlilik ve akrabalarına yakın olma isteği gibi nedenlerle gelmişlerdir. Ancak göç, ekonomik sıkıntılar, dişlanma ve çevreye uyum problemlerine yol açmaktadır. Bu sorunlar, Çingenelerin sosyo-ekonomik dezavantajlarının yanı sıra kimliklerinden kaynaklanan başka sorunlara da neden olmaktadır. Malatya'ya daha önceden göç edenlerin, yakın zamanda göç edenlere göre, ekonomik imkânları, geçinme stratejileri, kentlileşme düzeyleri ve siyasal bilinçleri görece daha yüksektir. Önceden göç eden Çingeneler, sonradan göç eden Çingeneleri genellikle "asıl Çingene" olarak damgalamakta ve "Çingenelik"i sonradan gelenlere devretmeye çalışmaktadır. $\mathrm{Bu}$ durum, görece daha yerleşik olanların "Çingeneliklerini devretme", "Çingenelikten kurtulma", böylece "topluma eklemlenme" çabası içerisinde oldukları şeklinde yorumlanabilir.

Çingeneler çoğunlukla kalabalık aile özelliği sergilemektedirler. Yedi kişi ve üstü nüfusa sahip hanelerin sayısı oldukça yüksektir. Hanehalkı nüfusunun fazla olması Çingenelerde bazı sosyo-ekonomik dezavantajlara yol açmaktadır. İkamet ettikleri konutlar yaşamaya elverişli değildir. Genellikle gecekondu ve baraka tipi konutlarda yaşamaktadırlar. Malatya'nın kenar mahallelerinde, özensiz bir şekilde inşa edilmiş, sağlık koşullarına uygun olmayan konutlarda yaşamaktadırlar. Böyle konutların yaygın olduğu mahalleler, birer çöküntü alanı görünümünü vermektedirler.

Çingenelerin çoğu ücretsiz genel sağlık sigortasından faydalanmakla birlikte neredeyse tamamının, herhangi bir sosyal güvencesi (SGK, Emekli Sandığı vb.) bulunmamaktadır. Çingenelerin gelir durumları oldukça düşüktür. Çingenelerin neredeyse tamamı, dört kişilik bir ailenin, sağlıklı, dengeli ve yeterli beslenebilmesi için gerekli ortalama aylık gelire sahip değillerdir. Kazançlarının hemen tamamı ise, beslenme gibi temel ihtiyaçlara harcanmaktadir.

Çingenelerin neredeyse tamamının herhangi bir mesleği yoktur. Eğitim düzeylerinin düşük olması, işe alınmalarında karşılaştıkları önyargılı tutum, dışlanma, geleneksel mesleklerinin (elekçilik, sepetçilik, kalaycılık, bakırcılık vb.) ekonomik geçerliliğini kaybetmesi, itibarsız ve tehlikeli/riskli işlerde çalışmalarına neden olmaktadır. Bu bağlamda, erkekler daha çok vasıf gerektirmeyen işlerle uğraşırken, kadınlar daha çok, gündelikçilik, bohçacılık, dilencilik gibi işlerle uğraşmaktadırlar. Çingene algısı ile bütünleşmiş hurdacılık, dilencilik, hamallık, işportacılık gibi marjinal işler, Çingenelerin toplumsal statüsü ile özdeşleşmekte ve Çingeneler için bir tercihten çok zorunluluğa dönüşmektedir.

Çingeneler yaşadıkları toplum içerisinde sosyoekonomik/kültürel açıdan oldukça dezavantajlı bir gruptur. $\mathrm{Bu}$ bağlamda yoksulluğun en şiddetli hallerini deneyimlemektedirler. Yoksulluklarının nedeni olarak çoğunlukla "Çingenelik”lerini göstermektedirler. Çingeneliklerinden dolayı ekonomik hayattan dışlandıklarına, iş bulamadıklarına bunun da yoksulluğa neden olduğuna inanmaktadırlar. Çingeneler, yoksulluklarını aynı zamanda vasıfsızlıklarına da bağlamaktadırlar. Çingenelerde vasıfsızlık, kendilerine özgü meslekleri icra edememeleri, konar-göçerlikten dolayı sürekli ve düzenli çalış(a)mama gibi durumlardan kaynaklanmaktadır.

Çingeneler, Çingene oldukları için sosyal dışlanmaya maruz kalmaktadırlar. Çingene olmayan komşuları tarafından, ikamet ettikleri mahallelerden sıkça dişlanmaktadırlar. Ayrıca, işyerlerinden, ibadethanelerden (cami, cem evi) ve özellikle okuldan dışlanmaktadırlar. Ayrıca Çingenelerin bir kısmı, bazı Çingenelerin norma uymamaları, suç işlemeleri, dilencilik yapmaları gibi nedenlerden dolayı dışlanmalarında, Çingenelerin de paylarının olduğunu düşünmektedir.

\section{Kaynakça}

Akkan, Başak Ekim \& Deniz, Mehmet Baki \& Ertan, Mehmet (2011). Sosyal Dışlanmanın Roman Halleri. İstanbul: Sosyal Politika Forumu.

Akkan, Başak Ekim \& Deniz, Mehmet Baki \& Ertan, Mehmet (2014). Dezavantajl Gruplar ve Sosyal Politika. İçinde: Betül Altuntaş (Ed.), Yoksulluğun ve Sosyal Dışlanmanın Romanlaşması (s.115-132). İstanbul: Nobel Akademik Yay.

Alp, S. \& Taştan, N. (2011). Türkiye'de Irk ve Etnik Köken Temelinde Ayrımcılı̆̆ı̆ İzlenmesi Raporu. İstanbul: Bilgi Üniversitesi İnsan Hakları Uygulama ve Araştırma Merkezi.

Bourdieu, Pierre (2006). Pratik Nedenler. Hülya Uğur Tanrı̈̈ver (Çev.). İstanbul: Hil Yayınları.

Can, Kemal (2007). Yoksulluk Halleri. İçinde: Necmi Erdoğan (Ed.), Yoksulluk ve Milliyetçilik, s. 175-202. İstanbul: İletişim Yayınları.

Erder, Sema (2001). Istanbul'a Bir Kent Kondu: Ümraniye. İstanbul: İletişim Yayınları.

Fundación Secretariado Gitano (FSG) (2010). Türkiye'de Romanların Durumu Türkiye'de Çalışma ve İnsana Yakışır İş Koşullart Sorunlart. (Erişim: 10.03.2014, http://ec.europa.eu/employment_social/progress/index en.html

Giddens, Anthony (2008). Sosyoloji. Cemal Güzel (Çev.). İstanbul: Kırmızı Yayınları.

TÜİK (2016). Türkiye Hanehalkı Ortalaması. (Erişim: 12.03.2018).https://www.tuik.gov.tr/Gosterge.do?metod $=$ IlgiliGosterge $\&$ sayfa $=$ giris $\& \mathrm{id}=353$. 
Işık, O. \& Pınarcıoglu, M. (2003). Nöbetleşe Yoksulluk: Sultanbeyli Örneği İstanbul: İletişim Yayınları.

İlhan, Süleyman (2013). Kentsel Yoksulluğu Yeniden Düşünmek. İçinde: Ömer Aytaç \& Süleyman İlhan (Ed.), Kentsel Yoksulluğun Anlam Dünyast (s. 169-220). Ankara: Birleşik Dağıtım.

Kempen Van, Ronald (2002). Poverty Pockets and Social Exclusion: On the Role of Place in Shaping Social Inequality”, Içinde: P. Marcuse \& R. Van Kempen (Ed.), Of States and Cities: the Partitioning of Urban Space. Oxford: Oxford University Press.

Kolukırık, Suat (2008). Türkiye'de Rom, Dom ve Lom Gruplarının Görünümü. Hacettepe Üniversitesi Türkiyat Araştırmaları Enstitüsü, 8, 145-153.

Kolukırık, Suat (2006). Tarlabaşı Çingenelerinde Dilin Sosyal Işslevi. Akademik Araştırmalar Dergisi, 31, s. $197-$ 209.

Madanipour, Ali (2003). Social Exclusion In European Cities: Process, Experiences and Responses. İçinde: Ali Madanipour \& Goran Cars \& Judith Allen (Ed.), Social Exclusion and Space. London: Routledge.

Marsh, Adrian (2008). Biz Buradayı! Türkiye'de Romanlar, Ayrımcr Uygulamalar ve Hak Mücadelesi. İçinde: E.Uzpeder, S. Danova/Roussinova, S. Özçelik, S. Gökçen, EDROM, ERRC, HYD. Türkiye Çingenelerinin Tarihi Hakkında. İstanbul: Mart Matbaacılık.

Önen, Selin (2011). Çingenelerin Sosyal Haklara Erişimindeki Zorluklar: Roman ve Dom Topluluklarl Karşılaştırması. III. Sosyal Haklar Uluslararası Sempozyumu Bildiri Kitabı. Kocaeli, s. 465-481.

Özkan, Ali Rafet (2010). Çingenelerin Kökeni ve Türkiye'de Çingeneler, Bir Çingene Yolculuğu, (Editör: Hasan Suver, Başak Kara, Aslınur Kara) İstanbul: Fatih Belediye Başkanlığı, ss.9-69.

Sennett, Richard \& Cobb, Jonathan (1972). The Hidden Injuries of Class. London: Faber and Faber.

Standing, Guy (2014). Prekarya, Yeni Tehlikeli Sinıf. Ergin Bulut (Çev.). İstanbul: İletişim Yay.

Wacquant, Loic (2011). Kent Paryalarl: Illeri Marjinalliğin Karşılaştırmalı Sosyolojisi. Mehmet Doğan (Çev.). İstanbul: Boğaziçi Üniversitesi Yayınevi.

Wilson, Franklin D. (2003). Ethnic Niching and Metropolitan Labor Markets. Social Science Research, 32, s. 429-466.

Radikal Gazetesi (2016). Sosyal Dışlanma Tehdidi Altında Romanlar. (Erişim: 20.01.2016), www.radikal.com.tr, http://www.radikal.com.tr/radikal2/sosyal-dislanmatehdidi-altinda-romanlar-875162/

Y1lgür, Egemen (2012). Nişantaşı Teneke Mahallesi: Teneke Mahalle Yoksulluğundan Orta Sinıf Yerleşimine. İstanbul: İletişim Yayıncılık. 

